\title{
Practices for Using Social Media in Students of Islamic Boarding School Collaborating with IAIN Purwokerto and its Implications on the Establishment of Students Cultural Hybridity
}

\author{
A Basit ${ }^{1}$ \\ Institut Agama Islam Negeri (IAIN) Purwokerto, Purwokerto, Indonesia \\ abdulbasit@iainpurwokerto.ac.id $\left.{ }^{1}\right\}$
}

\begin{abstract}
This study explains the practice of using social media among students who have different backgrounds and policies at Islamic boarding schools. The implications of these differences produce a unique and heterogeneous hybrid culture. In this study, researchers used a type of qualitative research with a phenomenological approach. Data were obtained from 25 Islamic boarding schools in collaboration with IAIN Purwokerto through participant observation, in-depth interviews, and documentation. The results of this study indicate that the limited time given by Islamic boarding schools in using social media does not discourage them from using it. Furthermore, social media is able to change the old students' culture which is shown by their simplicity, obedience, courtesy, and deep understanding of religious and social-community issues to be a hybrid culture which is hedonic, egalitarian, and instant in religious and social issues.
\end{abstract}

Keyword: Social Media, Cultural Hybridity, Students, IAIN Purwokerto And Islamic Boarding School

\section{Introduction}

Since the emergence of Geo Cities in 1995 which serves web hosting to build social networks, the development of social media has attracted the attention of the public and scientists. In the report "Digital Around the World 2019", it was stated that out of a total of 268.2 million people in Indonesia, 150 million of them had used social media or around 56 percent and the average time spent was around 3 hours 26 minutes [1].

Whatsapp is a social media that is widely used by the public. Then followed by other social media as Facebook, YouTube, Instagram, Twitter, and so on. Interestingly, this social media has unique characteristics compared to other cyber media, including social media forming social networks between users, whether they know each other or not. Then information becomes an important keyword on social media. Information becomes a commodity that is produced, exchanged, and consumed so that information becomes a valuable commodity and becomes new capitalism[2].

The existence of social networks and information between users will certainly bring individual and social values that exist in the user community. Social media can shape new 
ways of religion or will shape "digital religion" [3] and can shape the culture of society. One of the important new cultures to be explored is the hybrid culture that has grown in the boarding school environment.

Research on the use of social media among students is relatively rarely carried out by researchers. [4]wrote about "Gadget culture at Islamic boarding schoolsin Collaboration with IAIN Purwokerto". According to him, "the culture of copy-paste, like and share, virtual solidarity, and selfies have penetrated in Islamic boarding schools". However, the article has not examined the implications of the use of gadgets on the formation of hybrid culture. Likewise with Ali's research that examines young women at Rawalpindi and Islamabad that social media provides benefits for their academic activities[5]. Nurdin and Rusliresearched on the use of social media for da'wah activists[6]. Pomerant, Hank \& Sugimoto examined the social influence of social media[7]. Pulido examined state policies in the use of social media in Higher Education[8]. Bullock do research on usage social media structured by public organizations[9]. There are many other researchers who study the use of social media for the needs of the community or institution. However, research on the use of social media and its implications in shaping hybrid culture has not been conducted.

The term culture is a term that is popular among the people. Therefore this term always presents in various disciplines of the social sciences, even in the natural sciences. When talking about humans, certainly it will be studied about culture. Scientists understand culture differently, some understand "culture" as being a construct "outside of the individual" while identity is "inside of the individual" [10]. Trompenaars[7] defines culture as a three-layered concepts. The outer layer is made up of apparent symbols, traditions and rituals of culture. These represent "symbols of a deeper level of culture". The second or middle layer is made up of values and social behaviours of members of the community. The core or inner layer is based on frames of reference including underlying assumptions about the world, life and human existence. Further analysis reveals that culture can be seen as "the whole way of life of a people or group. In this context, culture (sic) includes all the social practices that bond a group of people together and distinguish them from others" [11].

Furthermore,Samovar explained culture is the basis of the structure, stability, and security that both individual and a society must possess if they are to maintain themselves[12]. Culture provides this foundation because it is dynamic and develops along the lines of self and societal survival. In essence, culture is the medium through which a society survives and perpetuates itself by the survival, reproduction, and training of the individuals who comprise the society. An example of culture works to perpetuate society can be found by looking at a cultural custom in Africa and seeing how it operates to benefit a part of African tribal society.

Likewise with the term hybrid. This term first refers to the development of new combinations by crossing one plant or fruit with another. Then developed in genetics and biogenetic science. In social science, this term is introduced in anthropological studies of religion, language, and culture [13]. Bhabha explained, "Hybridity is the sign of the productivity of colonial power, its shifting forces and fixities; it is the name for the strategic reversal of the process of domination through disavowal". He gives a definition of hybridity as "the name of this displacement of value from symbol to sign that causes the dominant discourse to split along the axis of its power to be representative, authoritative" [14].

From the term culture and hybrid came the term hybrid culture which was interpreted as a mixed culture that was different from the original culture. At present it is very difficult to find the roots, identities, and cultural meanings that are essential in a particular society or community. The power of cultural roots that were once attached to the identity of certain 
communities and applied through rituals and traditions, from day to day more and more are fading or transforming into an inevitable Hibridty.

Santri (here is referred to students) is a term for someone who is studying at a boarding school, both students, university students, teenagers, or adults. Students with various backgrounds, they have certainly bring their respective cultures that are sourced from the results of family education and social environment before boarding school. When they meet in a community at the boarding school, there will definitely be assimilation, negotiation, and conflict. How this process occurs and what hybrid culture will emerge from the struggle is an interesting study to do.

Islamic boarding school is the oldest Islamic education institution in Indonesia. Since its emergence in the Walisongo era to the present, the role of islamic boarding schools in the world of education could not be doubted [15]. In fact, in recent years, many have modeled and developed Islamic Boarding School education models into alternative education models that are of public interest, such as boarding schools that have sprung up in various regions in Indonesia.

The researchers also have shown significant evidence about the important role of Islamic Boarding schools in education [16]-[22] and several other researchers have explained the role of Islamic Boarding Schools in the world of education, both in terms of learning, tradition, management, communication, and social change.

In addition to Islamic Boarding School as an Islamic educational institution is often used as social institutions that play a role in empowering the community. Islamic boarding schoolis involved in religious activities of the community, such as Islamic study place, slametan, remembrance assemblies, and grand Islamic preaching. The Islamic Boarding School is also involved in economic, political and social culture activities that exist in the community. The involvement of Islamic Boarding School in community empowerment is inseparable from the central role of Kyai atIslamic Boarding School. Kyai has a multi-role as instructors, leaders of Islamic boarding schools, community leaders, drivers of change, and various other functional roles. All of these roles are integrated in a Kyai. Therefore, a Kyai for students and the surrounding community can be used as a figure and role model that can change people's lives[23].

Along with the changing times and demands for change management, the role of Kyai in Islamic Boarding School has decreased with the presence of a management system in Islamic Boarding School. Kyai is no longer used as a central figure or the only policy maker or decision maker. There is a management system that regulateswhere Kyai's position is done. This management system also provides opportunities for many parties to be involved in raising Islamic Boarding Schools. Islamic boarding schools can open cooperation with various parties such as capital owners, banks, school committees, teaching staff, parents of students, government agencies and the private sectors.

In the context of the empowerment of Muslims, Islamic Boarding School which have a wide network and well-organized management system certainly have a great opportunity to take part in the community. Through its network, Islamic Boarding Schoolis able to connect the community and stakeholders in empowering Muslims. Likewise, with a good management system, Islamic Boarding Schools is able to manage their potential to the maximum and can become bargaining power in the community. If the Islamic Boarding School only rely on the capabilities and knowledge of the Kyai, without the support of a solid management system, it will certainly experience difficulties in empowering Muslims. One form of networking carried out by Islamic Boarding School is to conduct a learning process in partnership with universities. 
Another important role of Islamic Boarding School is to maintain and develop a culture of students that is independent, disciplined, simple, and obedient in carrying out religious teachings [24]. When students are associated with digital technology, especially social media, the culture of the students will experience adjustments to the development of information technology. In this point, a hybrid culture which is owned by students ofIslamic Boarding School will be born.

Research on the use of social media and the formation of a hybrid culture is important to strengthen previous findings that social media is a media that is widely used by the public and can penetrate to all circles, including students in Islamic boarding schools. In fact, social media has the power to influence one's culture or community. In addition, this research find a hybrid culture among millennial students. This research didn't conduct a quantitative study of the effect of the use of social media on the formation of student culture. The study was conducted qualitatively in order to explore and interpret the meanings or behaviors carried out by students in Islamic boarding schools. Through a qualitative study, it is expected to be able to comprehensively explore the existence of a hybrid culture among Islamic boarding school students.

\section{Method}

This research uses qualitative research. Remembering the data examined is holistic and natural or in accordance with the field situation as it is [25]. Data were obtained directly from Islamic boarding school in collaboration with IAIN Purwokerto through participant observation, in-depth interviews and documentation. The direct data is analyzed using the theory of symbolic interactionism.

Then to facilitate the research work process in the field, researchers use a phenomenological approach. Phenomenologists see human behavior as a result of their interpretation of their world. The task of a phenomenology researcher is to capture the process of interpretation by someone. To be able to capture this process requires empathic understanding or the ability to absorb and express feelings, motives, and thoughts that are behind the actions of others [10]. In connection with this research, researchers will explore experience, awareness, and capture the meanings of the behavior (social actions) of the managers, clerics, and students of Islamic boarding school in collaboration with IAIN Purwokerto from their own perspective. The findings are then analyzed using the theory used and concluded.

\section{Results and Discussion}

The Islamic boarding school program for IAIN Purwokerto students has been applied since 2011. The policy is based on the complaints and suggestions from the stakeholders, parents, and lecturers that the IAIN alumni's ability in Al-Qur'an reciting and writing is very low. So, it needs to do standardization and guidance for the students that have not had that competence. Considering that IAIN Purwokerto does not have an area to build a dormitory, so the rector, A. Luthfi Hamidi had an idea to cooperate with Islamic boarding school around the campus. The idea was accepted by the board of Islamic boarding school and then carried out the agreement to do some processes of character guidance, Al-Qur'an reciting and writing or Baca Tulis Al- 
Qur'an (BTA), knowledge and practicing of worship or Pengetahuan dan Pengamalan Ibadah (PPI), also other materials that are usually done in Islamic boarding school.

Initially, there were 7 Islamic boarding schools in cooperation. Along with the increasing of the students' quantity but the capacity of the Islamic boarding school was not enough, so there were many new Islamic boarding schools. In 2019, the total number of Islamic boarding schools of IAIN partner is 25 with 4750 students. In managing the students in Islamic boarding schools, the full policy is given to the Islamic boarding school itself. IAIN Purwokerto gives the BTA-PPI guidance book, supervises and monitors, and the partnership between IAIN Purwokerto and the Islamic boarding school is a pseudo partnership[26].

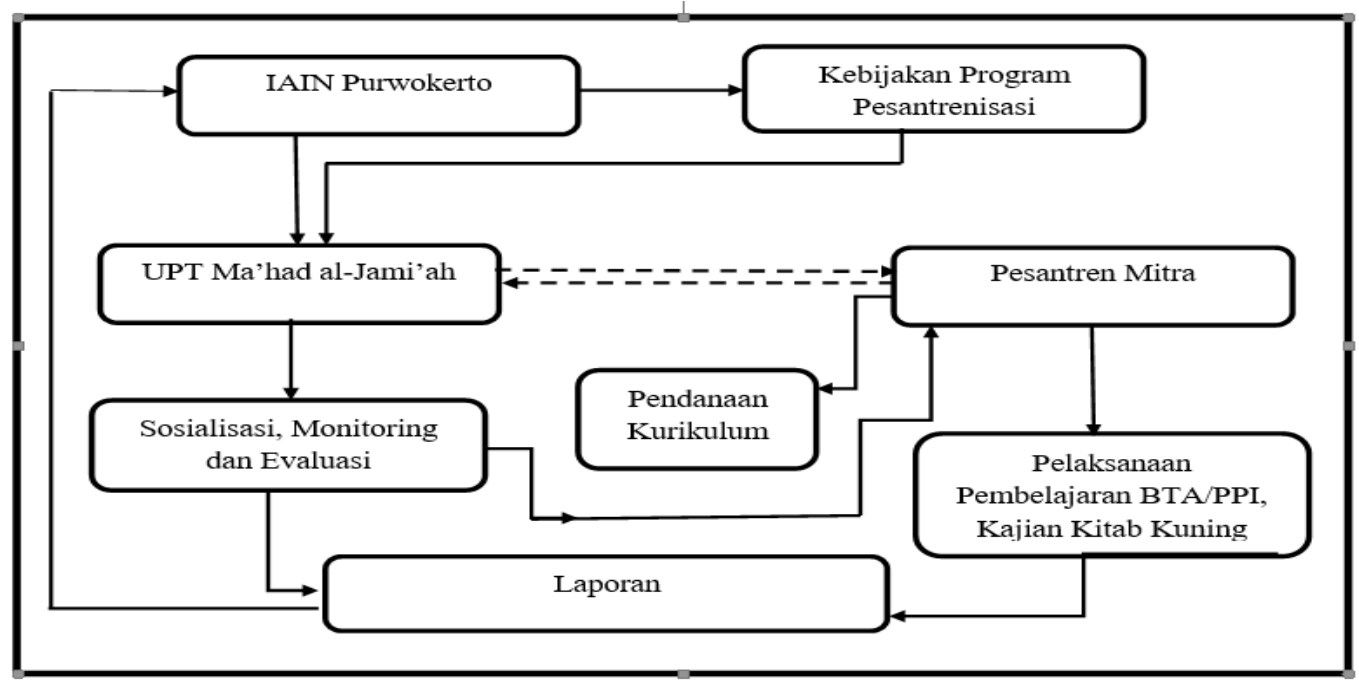

Related to the use of social media in each Islamic boarding school has a different policy. Asa result of observation, there are three policy patterns in using social media in Islamic boarding schools, the partner of IAIN Purwokerto, first, Islamic boarding school facilitates the internet with the together responsibility bill and the students may use the social media. The students have responsibility and trust to use the media wisely and do not break up the religious and social norms. Second, the Islamic boarding school facilitates internet and the students may not bring an android handphone so they could not use social media. Third, the Islamic boarding school doesn't facilitate the internet, but the students may use social media with rules that it would not disturb the learning process in Islamic boarding school.

Although there are some different policies, all the students who live in an Islamic boarding school could not stop using social media. They need social media as the information media and social network, especially for supporting their academic activity and organization. Because of that, the Islamic boarding school is one of an institution that could not deny the technology penetration and social media that recently dominates society greatly. Not only the young students and the caretakers of Islamic boarding school but also the board and Kyai have social media too. This condition implies to the students' attitude in using social media. Many researchers have examined the effect or implication of using social media either in the field of education, religion, social, and politic.

Hasna and other students get the internet facility and they are free to use social media, they do not have any difficulties in fulfilling the individual, social, or academic needs. She and her friends are responsible for usingsocial media. When the teaching-learning processes happen in 
the Islamic boarding school, none of the students brings a handphone and they obey the advice or materials from the teacher to stay away from sinful behavior, one of them is to prevent accessing the social media or internet that contain sexual or gossip content. However, some students who stay awake and lately join the together prayer or recitation because of social media. Different from Hasna, Atik, Rifqi Mu'akhiroh that live in the Islamic boarding school, they may not bring an android handphone, they feel there is no difficulty though they do not use social media. Because the information related to the academic and boarding activities are informed directly by the caretakers that are trusted by the board of boarding school to bring android handphone. When there are some assignments from campus, they find them in internet rental or using campus wifi.

Explicitly, all the students of Islamic boarding school which are also university students live in Islamic boarding school the partner of IAIN Purwokerto use social media. The difference is only the usage intensity. The most favorite social media for the students are whatsapp, youtube, and instagram. According to Nadia Maula, one of student lives in AnNajah Islamic boarding school said "I use whatsapp more to make community network among students and it is for information media of Islamic boarding school, academic activities, and students' activities.

The use of social media certainly gives some implications in forming the students' culture. The basic change is related to the way of students' thinking and attitude. In the way of thinking, the students have various thinking way and there are some changes in the students' performance, life style, and attitude that live in the digital era compared to the students in the farming and industry era. The change of thinking way creates hedonism that brings up the popular culture by social media that emphasizes the emotion and satisfaction than intellectuality; the goals of life are enjoying good time happily and think instantly. So, one of the factor influences the attitude changing is beyond group interaction, beyond group interaction is interaction to social media communication means made by human culture.

Students who only prioritize social media rather than looking at the circumstances around them has implications for a sense of caring for the surrounding environment. Not only that, students who used to have a life of simplicity in behavior and lifestyle and have a frugal life are now experiencing changes. The lifestyle of simplicity in behavior and lifestyle begins to differ from the past students, because it has followed developments in communities outside the Islamic Boarding Schools. The life of students in activities where students used to only have activities in the study of religious books, but students now are not only activities in the study of religious books but are preoccupied with social media.

In addition, the interaction of students gave birth to cooperation between students like mutual cooperation, please help, have a sense of care between students, remind one another and communicate with each other so that in the boarding school born a sense of kinship and harmony. In the past, there were no students who competed with each other even though in the life of the Islamic Boarding Schools there were differences in interests and goals because the former students could accept differences in interests and goals that were found in each of the other students so that they could adjust to the differences.

In addition to changes in social behavior there is also a change in religious behavior such as discipline of regulations. The purpose of discipline in this case is the observance and attitude of the students' responsibility towards the regulations relating to Islamic boarding schools. Before the rise of social media, students were very obedient to Islamic boarding school regulations, they were guided and obeyed by the rules implemented by Islamic boarding schools. 
In addition to some of the changes above also occurred cultural changes with the formation of assimilation, students can easily see and imitate foreign cultures by looking at social media. In addition, moral degradation occurs which tends to deviant behavior. This is as a result of the excessive adoption of external culture that is not controlled by students, causing conflicts in the regulation of boarding schools.

\section{Conclusion}

IAIN Purwokerto applies Islamic Boarding School program for students, most millennial students are more active in social media because they think that social media is a primary need. There are three policies in the use of social media at Islamic Boarding School in collaboration with IAIN Purwokerto. The first is that Islamic Boarding Schools facilitates the internet at a shared cost and is allowed to use social media. Secondly, Islamic boarding schools do not facilitate the internet and are not allowed to bring Android's hand phone. Third, Islamic boarding schools do not facilitate the internet but students are allowed to use social media with rules that do not interfere with the learning process in boarding schools. The use of social media have implications in the formation of hybrid culture. A very fundamental change is related to the varied and inductive mindset, performance, lifestyle of student's behavior and cultural changes that are hedonic, egalitarian and instant in matters of religion and social problems.

\section{References}

[1] W. K. Pertiwi, "Digital A Round the Word." .

[2] R. Nasrullah, Media Sosial Perspektif Komunikasi, Budaya, Dan Sosioteknologi. Jakarta. Jakarta: Simbiosa Rekatama Media, 2015.

[3] Heidi A. Campbell, Digital Religion: Understanding Religious Practice in New Media Worlds. London: Routledge, 2013.

[4] W. Warto, "Budaya Gadget di Pondok Pesantren Mitra IAIN Purwokerto," IBDA`J. Kaji. Islam dan Budaya, vol. 15, no. 2, pp. 346-364, 2018.

[5] S. Ali, "Social Media Usage among Teenage Girls in Rawalpindi and Islamabad," Glob. Media J., vol. 16, no. 31, p. 1, 2018.

[6] Nurdin and Rusli, "Paper presented at 12 th Annual Conference on Islamic Studies ( ACIS ), 05-08 November 2012 in Surabaya, Indonesia MUSLIM SCHOLARS : A POSSIBILITY OF ADOPTION AND USE FOR," Pap. Present. 12 th Annu. Conf. Islam. Stud. ( ACIS ), 05-08 Novemb. 2012, no. October 2012, pp. 1-17, 2012.

[7] J. Pomerantz, C. Hank, and C. R. Sugimoto, "The state of social media policies in higher education," PLoS One, vol. 10, no. 5, pp. 1-18, 2015.

[8] C. M. Pulido, G. Redondo-Sama, T. Sordé-Martí, and R. Flecha, "Social impact in social media: A new method to evaluate the social impact of research," PLoS One, vol. 13 , no. 8 , pp. 1-21, 2018.

[9] K. Bullock, "The police use of social media: Transformation or normalisation?," Soc. Policy Soc., vol. 17, no. 2, pp. 245-258, 2018.

[10] D. and J. Nunan and Choi, Language and Culture: Reflective Narratives and the Emergence of Identity. Taylor \& Francis, Rutledge, 2010.

[11] M. Reid Thomas, Language and Social Life. Britis Council.

[12] et. a. Samovar, Understanding Intercultural Communication. California: Wadsworth 
Publishing Company, 1980.

[13] J. N. Pieterse, "hybridity, so what?," Theory, Cult. Soc. 18, vol. (2-3), pp. 219-245, 2001.

[14] H. K. Bhabha, The Location of Culture. London: Routledge, 1994.

[15] S. Ni 'am, "Pesantren: the miniature of moderate Islam in Indonesia," Indones. J. Islam Muslim Soc., vol. 5, no. Number 1, pp. 111-134, 2015.

[16] Z. Dhofier, Tradisi Pesantren: Studi tentang Pandangan Hidup Kyai, VI. Jakarta: LP3ES, 1994.

[17] K. A. Steenbrink, Pesantren Madrasah Sekolah: Pendidikan Islam dalam Kurun Moderen. Jakarta: LP3ES, 1994.

[18] Mastuhu, Dinamika Sistem Pendidikan Pesantren. Jakarta: INIS, 1994.

[19] M. Van Bruneissen, Kitab kuning, pesantren dan tarekat: Tradisi-tradisi Islam di Indonesia bandung: Mizan, 1999.

[20] R. Lukens-Bull, A Peacefull Jihad. Palgrave Macmillan, 2005.

[21] A. Mas'ud, Dari Haramain ke Nusantara: Jejak Intelektual Arsitek Pesantren. Jakarta: Kencana, 2006.

[22] Suparjo, "Komunikasi Interpersonal Kiai-Santri: Studi Tentang Keberlansungan Tradisi Pesantren di Era Modern," UIN Sunan Kalijaga Yogyakarta, 2013.

[23] M. F. Isbah, "Examining the Socio-Economic Role of Islamic Boarding Schools ( Pesantren ) in Indonesia.," School of Humanities and Social Sciences UNSW Canberra, 2006.

[24] Lyn Parker, "THE EXPERIENCE OF ADOLESCENT STUDENTS IN MODERNIST ISLAMIC BOARDING SCHOOLS IN WEST SUMATRA, INDONESIA," 2008.

[25] Muhadjir, "Metode Penelitian Kualitatif: Pendekatan Positifistik dan Rasionalistik telaah studi teks dan penelitian agama.".

[26] S. Iskarimah, "Model Kemitraan Program Pesantrenisasi IAIN Purwokerto," IAIN Purwokerto, 2017. 